\title{
Disfluency, Speech Rate, and Communication Attitude Differences According to Gender and Age in Adults Who Do Not Stutter
}

\author{
Moonja Shin ${ }^{a}$, Kyungjae Lee ${ }^{\mathrm{b}}$ \\ ${ }^{a}$ Department of Speech-Language Pathology, Chosun University, Gwangju, Korea \\ ${ }^{b}$ Department of Audiology and Speech-Language Pathology, Daegu Catholic University, Gyeongsan, Korea
}

Correspondence: Kyungjae Lee, PhD Department of Audiology and Speech-Language Pathology, Daegu Catholic University, 13-13 Hayang-ro, Hayang-eup, Gyeongsan 38430, Korea Tel: $+82-53-850-2543$

Fax: $+82-53-359-6780$

E-mail: kjlee0119@cu.ac.kr

Received: October 2, 2017

Revised: November 23, 2017

Accepted: November 29, 2017

This study was supported by research fund from Chosun University, 2017.

\begin{abstract}
Objectives: Diverse speech samples should be analyzed due to variability in stuttering. However, there are limited Korean studies on the variability of disfluencies in adults who do not stutter for comparison with assessment data of adults who stutter. In addition, even though speech rate can be an indicator of treatment progress, differences in previous studies' methodologies make them difficult to employ in a clinic setting. The primary purpose of the current study is to determine whether there are differences in disfluencies and overall speech rate of adults who do not stutter (AWNS) according to gender and age in order to provide clinical comparative data for adults who stutter. Differences in communication attitude according to age and gender were also analyzed. Methods: A total of 81 AWNS took part in the current study. Three compulsory tasks of the Paradise-Fluency AssessmentII were conducted and normal and abnormal disfluency scores of each task were determined. Overall speech rate was determined for reading samples, and a communication attitude test was also conducted. Two-way ANOVA and repeated measure ANOVA were used to determine whether differences in disfluency scores, overall speech rate, and communication attitude test scores were significant according to age, gender, and situation. Results: There were limited significant differences in disfluencies according to gender, with no significant difference according to age. There was a significant difference in overall speech rate according to age but not to gender. There was no significant difference in communication attitude according to age and gender. Conclusion: The results of the current study showed that both quantity and quality of disfluencies should be considered in stuttering assessment. In addition, in order to have a broader perspective on stuttering, more diverse age groups should be included in future studies.
\end{abstract}

Keywords: Disfluencies, Speech rate, Communication attitude, Stuttering assessment
말더듬은 말의 비유창성이 가장 큰 특징인 다면적인 장애이다 (Guitar, 2014; Manning, 2010). 예를 들어 Guitar (2014)는 말더듬 을 말의 비유창성인 핵심행동, 말더듬에서 빠져나오거나 이를 회피 하려는 행동인 부수행동, 그리고 말과 말더듬에 대한 부정적인 감 정과 태도 등 세 가지 구성요소로 말더듬을 설명하였다. 이에 말더 듬평가 역시 다면적이어야 하지만 가장 기본적인 측면은 비유창성 의 평가일 것이다. 말더듬평가는 대상자의 연령 등에 따라 그 평가 목표가 다양할 수 있으나 말에서 관찰되는 비유창성 빈도와 유형
등 비유창성 관련 평가를 통하여 대상자의 말더듬 유무, 중증도 등 을 평가한다(Manning, 2010; Riley, 2009; Sim, Shin, \& Lee, 2010).

이러한 말더듬의 유무 및 중증도 평가에서 가장 많이 사용되는 지표는 비유창성의 유형과 빈도이다. 비유창성은 말의 유창한 흐 름을 저해하는 요소로 연구자들에 따라 명칭과 세부 구분은 다를 수 있지만 크게 일반인들이 주로 보이는 비유창성, 혹은 정상적 비 유창성, 그리고 말더듬는 사람이 보이는 비유창성, 혹은 비정상적 비유창성으로 나눌 수 있다(Manning, 2010; Sim et al., 2010; Yairi 
\& Ambrose, 2005). Yairi와 Ambrose (2005)는 일반아동이 주로 보 이는 비유창성을 가성 비유창성(other disfluency, OD)이라고 하였 으며, 다음절 단어의 전체반복, 수정과 미완성 구, 간투사 등이 이 에 해당한다. 반면 말더듬아동이 주로 보이는 비유창성을 진성 비 유창성(stuttering like disfluency, SLD)이라고 하였으며, 단어의 부 분 반복, 일음절 단어의 전체반복, 연장과 막힘 등을 포함하는 비운 율적 발성 등이 이에 해당한다. 연구자와 평가도구에 따라서 다르 기는 하지만 이러한 정상적 혹은 비정상적 비유창성의 빈도측정을 통하여 일반인과 말더듬는 사람을 구분하고 중증도를 측정한다. 연구자에 따라 다르기는 하지만 일반적으로 정상적 비유창성과 비 정상적 비유창성의 총빈도가 $10 \%$ 를 넘거나 비정상적 비유창성의 빈도가 $3 \%$ 를 넘을 경우 일반아동이 아닌 말더듬아동으로 진단될 수 있다(Guitar, 2014). 이와 관련하여 국내 임상현장에서 주로 사 용되는 파라다이스-유창성 평가-II (Paradise-Fluency AssessmentII, P-FA-II; Sim et al., 2010) 역시 정상적 비유창성과 비정상적 비유 창성을 모두 평가하고 이를 바탕으로 말더듬 중증도를 측정하고 있다. P-FA-II는 성인의 경우 읽기, 대화, 그림 설명하기 등 다양한 과제에서 발화를 산출하게 하여 이러한 발화에서 나타나는 정상 적 비유창성과 비정상적 비유창성의 빈도를 측정한다. 특히 비정상 적 비유창성의 빈도에 가중치를 두어 점수를 산출하며 이러한 정 상적 비유창성과 비정상적 비유창성의 빈도의 합을 통하여 말더듬 중증도를 측정한다.

이러한 말더듬 빈도 측정과 관련된 외적 특성의 평가에서 일반 인 대상의 정보는 충분히 제공되어 있지 않다. 특히 말더듬의 중증 도가 약함 수준인 경우 말더듬성인과 일반성인을 구분할 수 있는 정보가 필요하지만 일반인과 관련된 국내 정보는 부족한 편이다. 예를 들어 P-FA-II에서 약함의 중증도로 평가되는 범위는 중학생 이상의 경우, 필수과제 총합이 11.45 점까지이며, $10 \% \mathrm{ile}$ 에 해당하 는 점수는 5.37 점이다. 반면 일반인의 경우 필수과제 총점의 평균 은 $6.52(\mathrm{SD}=5.94)$ 였다. 즉 P-FA-II의 총점 기준을 사용한다면 평 균적인 일반인의 경우 “약함” 수준의 비유창성을 보이는 것으로 판단될 수 있다는 것이다. 이와 관련하여 지금까지의 국내 일반인 을 대상으로 하는 비유창성 빈도 연구는 주로 학령전기 일반아동 이나 다른 문제 등이 있는 아동을 대상으로 한 연구, 혹은 노년층 등을 대상으로 한 연구가 주를 이루었으며 일반성인과 관련된 연 구는 부족한 편이다(Chon, Ko, \& Shin, 2004; Jeon, Kim, Shin, \& Chang, 2011; Kim, Lee, Choi, \& Choi, 2016; Lee \& Kwon, 2004; Lee, Sim, \& Shin, 2007; Shin, 2016). 일반적으로 아동과 노인층 집 단이 성인보다는 비유창성이 많은 편인데(Yairi \& Clifton, 1972), 이는 언어능력, 노화 등이 원인인 것으로 생각된다. 국내 연구의 경
우 55-84세의 노년층을 대상으로 비유창성 빈도의 차이를 살펴본 결과, 연령에 따른 비유창성의 빈도에서 유의한 차이가 관찰되었다 (Shin, 2016). 또한 이러한 노인층의 경우 한 장의 그림을 설명하는 과제보다 연속그림 설명하기와 같이 인지적 요구가 많은 과제에서 비유창성이 더 많이 관찰되었다. 또한 일반성인, 방송인 등을 대상 으로 비유창성 빈도 등을 측정한 연구가 있으나 이러한 결과를 PFA-II와 같은 임상도구 결과와 직접적인 비교를 하기에는 어려움이 있을 수 있다(Shim, 2005).

특히 비유창성은 개별적인 특성이 있으므로 집단별, 상황별 특 성을 살펴보는 것이 중요할 것이나 이와 관련된 표준화된 국내연구 역시 부족한 편이다. 비유창성의 가장 큰 특성은 이와 같은 가변성 으로 이를 해결하고자 P-FA-II에서도 다양한 상황에서의 말 샘플 을 분석한다. 예를 들어 P-FA-II에서는 중학생 이상의 경우 읽기, 말하기그림, 대화의 세 필수과제와 낱말그림과 따라말하기, 두 가 지의 선택과제를 제공하고 있다. 하지만 세 필수과제의 총합이 일 반집단과 말더듬집단, 두 집단 사이에서 어떻게 차이가 나타나는지 만 제공할 뿐, 과제별 차이는 제공하지 않고 있다. 가변성과 개별적 인 특성 등으로 인하여 말더듬성인이 각 과제에서 보이는 비유창 성 빈도는 차이가 날 수 있으므로 일반인들과 각 과제별 비교를 통 하여 대상자의 특성을 보다 면밀히 살펴볼 수 있을 것이다. 또한 PFA-II 지침서에 따르면 예비검사에서는 일반집단 총 26 명, 말더듬 집단 26 명 등 총 52 명을 대상으로 하였으며, 재규준화 연구에서는 일반집단 207명, 말더듬집단 총 289명 등을 대상으로 표준화작업 을 진행한 것으로 제시되었다. 하지만 일반집단 총 207명 중 중학생 이상은 81 명으로 기재되어 있고 이들의 연령 및 성별 등의 분포와 관련된 정보는 미진하게 제시되어 있다. 이에 성인이 각 상황별로 나타내는 비유창성 빈도와 관련된 정보는 말더듬성인의 평가에 유 용할 것으로 기대된다. 비유창성의 빈도에 영향을 주는 요인으로는 우선 전술하였듯이 연령이 있을 수 있다. 또한 말더듬이 여성보다 는 남성에게서 더 많이 나타나며, 일반인 역시 비유창성에 있어 유 사한 패턴을 보이는 것으로 알려져 있다. 예를 들어 학령기 아동의 경우 성에 따른 총 비유창성 빈도에서 유의한 차이를 보이지 않았 으나 학령전기 아동과 성인의 경우, 남성이 여성보다 더 많은 비유 창성을 보였다는 보고가 있었다(Bortfeld, Leon, Bloom, Schober, \& Brennan, 2001; Kools \& Berryman, 1971; Tumanova, Conture, Lambert, \& Walden, 2014). 하지만 이러한 연구들은 대화 상황 등 을 위주로 분석을 하였으며 전술하였듯이 다면적인 말더듬평가를 위해서는 다양한 말 샘플을 분석하여야 하므로 다양한 상황에서 의 성과 연령 등에 따른 비유창성의 차이를 살펴볼 필요가 있다. 비유창성의 빈도 이외에도 말속도와 같은 말 특성의 평가는 치 
료 중 진전의 지표 등으로 사용될 수 있어서 평가에서 주요한 요소 가 될 수 있으나 이와 관련된 국내연구 역시 부족한 편이다. 말속도 는 크게 조음동작의 효율성 등을 나타낼 수 있는 조음속도와 정보 전달의 효율성 등을 나타낼 수 있는 전체말속도로 구분된다(Gui$\operatorname{tar}$, 2014). 조음속도는 일반적으로 비유창성과 휴지기 등을 제외하 고 말을 산출하는 데 사용된 시간 동안 조음된 음절의 수 등으로 측정한다. 반면 전체말속도의 경우 비유창성과 일정시간 정도의 휴 지기 등은 포함하는 시간 동안 정보전달이 된 음절의 수로 측정한 다(Chon, 2015). 이 두 가지 속도 중 특히 전체말속도는 치료 중 진 전의 지표 등으로 사용될 수 있는데, 이는 앞서 기술한 바와 같이 전체말속도 측정에는 비유창성이 포함되기 때문이다. 즉 비유창성 이 상대적으로 많이 포함된 경우, 이러한 비유창성으로 인하여 제 한된 시간에 정보를 전달하는 음절의 수는 상대적으로 적을 것이 다. 반면 치료를 통하여 유창성이 향상된 경우, 정보를 전달하는 음 절 수의 증가로 인하여 전체말속도는 빨라질 것이다. 특히 임상에 서는 조음속도보다는 전체말속도의 측정이 상대적으로 용이할 수 있기에 이와 관련된 정보는 임상적으로 매우 중요성을 가질 수 있 다. 전술하였듯이 조음속도는 비유창성과 휴지기 등을 제외하고 시간을 측정하여야 정확할 수 있어 컴퓨터 프로그램 등을 사용한 정밀한 분석이 필수적이다. 하지만 전체말속도의 경우에는 연구자 에 따라 다르기는 하지만 1-2초 정도의 일반적인 휴지기는 포함하 여 측정을 한다(Chon, 2015; Guitar, 2014). 이에 현장에서는 초시계 등을 사용하여 읽기 등과 같이 음절 수가 미리 정해진 자료를 대상 으로 전체말속도를 상대적으로 쉽게 측정할 수 있을 것이다.

일반적으로 말속도는 상황에 따라 다르지만 읽기에서 가장 빠르 며, 연령에 따라 빨라지기는 하지만 일정 연령 이후, 즉 나이가 많은 노년기에는 근육조절 등의 문제로 인하여 차츰 느려진다고 한다 (Jeon et al., 2011; Walker, 1988). 예를 들어 대화 상황에서의 분당 말한 음절수로 구어속도를 측정한 결과, 50 대 성인의 평균 구어속 도는 210.90 syllable per minute (SPM)으로 70대 성인의 170.13 SPM보다 유의하게 빨랐다(Jeon et al., 2011). 하지만 노년층 집단에 서 성별에 따른 구어속도의 차이는 통계적으로 유의하지 않았다 (Jeon et al., 2011). 일반성인을 대상으로 전체말속도를 측정한 경우, 말하기에서는 4.20 음절/초, 읽기에서는 5.11음절/초였으며, 두 상황 의 전체말속도는 유의한 차이를 보였다(Shim, 2005). 이와 같은 일 반인의 전체말속도는 말더듬성인보다 빠르다는 보고가 있었다 (Lee, 2010). 예를 들어 긴 문장을 읽는 경우 일반인의 말속도는 초 당 5.85음절로 말더듬성인의 말속도 5.04음절보다 유의하게 빨랐 다(Lee, 2010). 반면 성별에 따른 말속도 차이와 관련해서는 남성이 여성보다 빠르다는 결과와 차이가 없다는 결과 등 비일관적인 결과
가 제시되었다(Ahn, Shin, \& Kwon, 2002; Jeon et al., 2011; Lutz \& Mallard, 1986; Robb, Maclagan, \& Chen, 2004). 이에 과제와 성별, 연령 등 매우 다양한 요인 등에 따라서 말속도는 영향을 받을 수 있 으므로 표준화된 절차를 이용한 정보를 제공한다면 임상적으로 참고할 수 있는 유용한 자료가 될 수 있을 것이다

더불어 다면적인 말더듬평가를 위해서는 의사소통태도 등을 평 가하여야 하나 이와 관련된 국내연구 역시 부족한 편이다. 말더듬 에 대한 인식은 학령전기에도 나타나며 국내 말더듬아동 역시 일 반아동과는 다른 의사소통태도를 보인다고 보고되었다(Lee, Sim, \& Lee, 2013). 하지만 말더듬아동의 경우에는 이러한 의사소통태 도가 성별에 따라 유의한 차이를 보이지 않으나 성인의 경우에는 다를 수 있다(Guttormsen, Kefalianos, \& Naess, 2015; Silverman \& Zimmer, 1979). 이와 관련하여 일반성인의 경우, 말더듬에 대한 태 도 역시 성별에 따라 유의한 차이는 아니지만 다른 패턴을 보인다 는 보고도 있었다(St. Louis, 2012). 이에 성별과 연령 등에 따른 의 사소통태도 차이를 살펴보는 것을 통하여 개별적인 진단 및 중재 가 가능할 것이다.

이에 본 연구에서는 다양한 연령대의 일반성인을 대상으로 비유 창성의 빈도와 말속도, 특히 전체말속도를 측정하여 말더듬성인 평 가의 기초자료를 제공하는 것을 주요 목적으로 하였다. 앞서 언급 된 국내에서 주로 사용되는 말더듬평가도구인 P-FA-II의 경우, 세 연령대로 구성되어 있으나 가장 높은 연령대의 경우 중학생 이상의 성인이 한 범주의 대상으로 제시되어 있다. 이에 보다 동질한 집단 의 특성을 연구하기 위하여 본 연구에서는 만 18 세 이상-60세의 성 인을 대상으로 연령대에 따른 차이를 살펴보고자 하였다. 더불어 성에 따른 차이도 살펴보고자 하였다. 특히 임상에서 자주 사용하 고 있는 자료들과 직접적인 비교가 가능할 수 있도록 임상현장에 서 가장 많이 사용되고 있는 P-FA-II의 평가자료를 사용하여 일반 인들의 자료를 구하였으며 조음속도보다는 임상가들이 보다 쉽게 측정할 수 있는 전체말속도를 측정하였다. 또한 전체말속도 측정에 서는 자유로운 발화를 대상으로 측정한 것이 아니라 발화음절 수 가 이미 확인이 된 읽기를 대상으로 하여 임상가들이 보다 더 쉽게 비교할 수 있게 하였다. 더불어 의사소통태도 역시 성과 연령에 따 라차이가 나타나는지 살펴보고자 하였다.

\section{연구방법}

\section{연구대상}

본 연구에서는 총 81 명(평균연령 36.56세, $\mathrm{SD}=10.54$, 범위:20-57세) 의 성인이 참여하였다. 참여자 중 20 대는 28 명(남 13 명, 여 15 명), 30 
대 17명(남 7명, 여 10명), 40대 23명(남 12명 여 11명), 50대 13명(남 5 명, 여 8명)이었으며 전체 남성은 37명(평균 연령 36.27세, $\mathrm{SD}=$ $10.68)$, 여성은 44 명(평균 연령 36.80 세, $\mathrm{SD}=10.53$ )이었다.

참여자들은 모두 고등학교 이상의 학력의 소지자였으며, 자기보 고에 따르면 말더듬과 언어, 인지, 행동, 심리 등의 문제가 없었다. 더 불어 실험자와의 상호작용에서 말더듬과 관련된 뚜렷한 문제가 관 찰되지 않았으며 모두 $3 \% \mathrm{SS}$ 이내의 말더듬빈도를 보였다.

\section{평가도구 및 분석방법}

참여자들에게 우선 대화, 읽기, 그림 설명하기 등과 같은 P-FA-II (Sim et al., 2010)의 성인대상 필수과제를 실시하였다. 이러한 필수 과제의 순서는 무순으로 실시하였다. 평가는 조용한 실내에서 평가 자와 참여자, $1: 1$ 로 이루어졌으며 모든 평가과정은 핸드폰 등을 이 용하여 비디오 녹화를 하였다. 더불어 P-FA-II의 의사소통태도 검 사를 실시하였다.

비유창성 분석은 P-FA-II의 지침을 따라 실시하였다. 대화의 경 우 실험자와 라포가 형성된 후의 대화를 대상으로 최소 300음절을 대상으로 분석을 실시하였다. 그림 설명하기 과제의 경우, 두 장의 그림을 사용하여 최소 300 음절 이상의 발화를 유도하여 이를 분석 하였다. 만약 대상자의 발화가 300 음절 이상이 되는 경우에는 이 를 모두 분석하였으며, 300음절이 되지 않는 경우에도 역시 대상자 의 발화를 모두 분석하였다. 읽기의 경우에도 역시 "안녕하세요 선 생님”과 “2002년 6월 22일” 두 가지의 읽기 자료를 모두 사용하여 발화를 산출하게 하였다.

비유창성 유형은 P-FA-II의 지침에 따라 정상적 비유창성과 비 정상적 비유창성으로 나누어 분석하였다. 정상적 비유창성으로는 주저(H), 간투사(I), 미완성 또는/그리고 수정(UR), 다음절 낱말이 나 구, 어절 등의 반복(R1)이었으며 비정상적 비유창성으로는 음소 반복, 단어부분반복 등을 포함하는 낱말보다 작은 단위에서의 반 복(R2)과 연장과 막힘, 깨진 낱말 등을 포함하는 비운율적 발성 $(\mathrm{DP})$ 이었다. 특히 정상적 비유창성이지만 질적 양상이 동반되거나 오랜 시간 동안 나타나는 경우에도 주저-비정상적 $(\mathrm{Ha})$, 미완성 또 는/그리고 수정-비정상적(URa), 반복1-비정상적(R1a) 등과 같이 역 시 비정상적 비유창성으로 분석하였다. 이렇게 산출된 비유창성 빈도와 분석대상 음절수를 바탕으로 정상적 비유창성 점수와 비 정상적 비유창성 점수를 산출하였다. 비유창성 점수는 100 음절당 발생빈도로 측정이 되나 비정상적 비유창성의 경우 1.5 배의 가중치 를 적용하였다.

전체말속도는 두 가지의 읽기 자료 중 “안녕하세요 선생님” 하나 만을 대상으로 전체말속도를 측정하였다. 전체말속도를 측정하기
위한 음성자료는 평가 비디오 자료에서 음성화일을 추출하여 사용 하였다. 전체말속도 측정은 Shim (2005), Chon 등(2004), Chon 등 (2015)이 제시한 방법을 사용하여 측정하였다. 우선 대상자 읽기자 료의 시작시간과 끝시간을 컴퓨터 프로그램(Praat; Boersma \& Weenink, 2013)을 이용하여 측정하였다. 또한 읽기자료에서 2초 이상의 휴지기간이 있는 경우 이러한 휴지기간 역시 컴퓨터 프로그 램을 사용하여 측정하였다. 읽기에 걸린 시간은 다음과 같은 방식 으로 측정하였다. 우선 읽기의 끝시간에서 시작시간을 빼고, 또한 2 초 이상의 휴지기간 있는 경우 이러한 휴지기간에서 2 초를 감하여 읽기에 사용된 시간을 측정하였다. 예를 들어 총 읽기에 걸린 시간 이 30 초이고 1 회의 휴지기간이 2.3 초인 경우, 2 초를 초과한 휴지기 0.3 초를 30 초에서 제한 29.7 초를 읽기에 걸린 시간으로 사용하였 다. 이렇게 측정된 읽기에 걸린 시간으로 읽기자료의 음절수(400음 절)를 나누어 전체말속도(음절/초)를 측정하였다. 만약 참여자가 읽기에서 실수를 하여 읽기 음절수가 400 음절이 아닌 경우에는 참 여자가 발화한 실제 음절수를 이용하여 전체말속도를 측정하였다.

\section{신뢰도 및 분석방법}

총 10 명의 참여자의 자료를 대상으로 비유창성 분석과 전체말속 도 측정의 평가자 간 신뢰도를 측정하였다. 평가자 간 신뢰도를 측 정하기 위해 언어재활사 자격증이 있는 언어병리학전공의 석사생 이 독립된 평가자로 자료를 분석하였다. 비유창성 분석의 경우 Gui$\operatorname{tar}$ (2014)가 제시한 일치도 공식을 적용하였을 때 $98 \%$ 의 일치도를 보였다. 전체말속도의 경우 상관관계로 측정한 평가자 간 신뢰도 $r=.99(p<.001)$ 이었다.

비유창성 점수, 전체말속도 그리고 의사소통태도점수가 성별과 나이집단(20대, 30대, 40 대, 50 대 등 네 집단)에 따라차이가 나타나 는지 이원분산분석(two-way ANOVA)을 실시하여 살펴보았다. 비 유창성 빈도의 경우 각 상황별 정상적 비유창성과 비정상적 비유 창성 점수, 전체 정상적 비유창성의 점수, 전체 비정상적 비유창성 의 점수, 총 비유창성 점수 등의 차이 등으로 나누어 살펴보았다. 또 한 상황별로 각 개인의 정상적 비유창성 점수와 비유창성 점수가 차이가 나타나는지 살펴보기 위하여 반복측정분석을 실시하였다.

\section{연구결과}

\section{성별과 나이에 따른 비유창성 점수}

본 연구 참여자의 성별과 나이에 따른 비유창성 점수는 Table 1 과 같다(Figures 1, 2). 우선 읽기에서 남성의 정상적 비유창성 평균 점수는 $.43(\mathrm{SD}=.46)$, 여성의 평균 점수는 $.24(\mathrm{SD}=.28)$ 였으며 이 
Moonja Shin, et al. • Disfluency and Speech Rate of AWNS

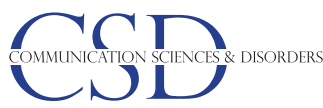

Table 1. Normal disfluency scores and abnormal disfluency scores of the participants

\begin{tabular}{|c|c|c|c|c|c|c|c|c|c|c|}
\hline & \multicolumn{2}{|c|}{$20 \mathrm{~s}$} & \multicolumn{2}{|c|}{$30 \mathrm{~s}$} & \multicolumn{2}{|c|}{$40 \mathrm{~s}$} & \multicolumn{2}{|c|}{$50 \mathrm{~s}$} & \multicolumn{2}{|c|}{ Total } \\
\hline & Male & Female & Male & Female & Male & Female & Male & Female & Male & Female \\
\hline \multicolumn{11}{|c|}{ Normal disfluency } \\
\hline Reading & $.38(.39)$ & $.28(.30)$ & $.48(.59)$ & $.68(.58)$ & $.27(.39)$ & $.13(.14)$ & $.34(.41)$ & $.26(.29)$ & $.43(.46)$ & $.24(.28)$ \\
\hline Conversation & $3.90(2.23)$ & $3.18(1.99)$ & $2.08(2.16)$ & 4.72 (3.62) & 3.31 (2.16) & $2.16(1.34)$ & $3.98(1.77)$ & $3.22(2.10)$ & $3.70(2.36)$ & $3.00(1.91)$ \\
\hline Picture & $2.93(2.13)$ & $3.02(1.73)$ & $2.26(1.82)$ & $3.20(2.46)$ & $2.95(1.98)$ & $1.68(1.49)$ & $3.45(2.87)$ & $3.56(1.74)$ & $3.00(2.33)$ & $2.84(1.80)$ \\
\hline Total & 7.21 (3.65) & $6.49(3.47)$ & $4.82(4.10)$ & $8.59(5.89)$ & 6.52 (3.81) & $3.97(2.47)$ & $7.77(4.29)$ & 7.04 (3.30) & $7.13(4.27)$ & 6.06 (3.39) \\
\hline \multicolumn{11}{|c|}{ Abnormal disfluency } \\
\hline Reading & $.29(.37)$ & $.28(.26)$ & $.35(.55)$ & $.23(.41)$ & $.31(.36)$ & $.17(.29)$ & $.45(.70)$ & $.12(.15)$ & $.35(.52)$ & $.22(.27)$ \\
\hline Conversation & $.34(.49)$ & $.21(.39)$ & $.19(.38)$ & $.90(1.31)$ & $.29(.50)$ & $.19(.21)$ & $.30(.57)$ & $.21(.33)$ & $.38(.66)$ & $.21(.36)$ \\
\hline Picture & $.27(.53)$ & $.30(.40)$ & $.15(.19)$ & $.20(.29)$ & $.23(.30)$ & $.25(.50)$ & $.57(.49)$ & $.30(.54)$ & $.20(.29)$ & $.23(.30)$ \\
\hline Total & $.90(1.07)$ & $.79(.77)$ & $.70(.87)$ & $1.33(1.83)$ & $.83(1.02)$ & $.54(.66)$ & $1.32(1.11)$ & $.63(.77)$ & $1.06(1.15)$ & $.70(.78)$ \\
\hline Total score & 8.12 (4.30) & 7.28 (3.72) & $5.52(4.91)$ & $9.93(7.49)$ & $7.36(4.36)$ & $4.51(2.42)$ & $9.09(5.03)$ & 7.67 (3.08) & $8.19(5.12)$ & $6.76(3.55)$ \\
\hline
\end{tabular}

Values are presented as mean (SD).

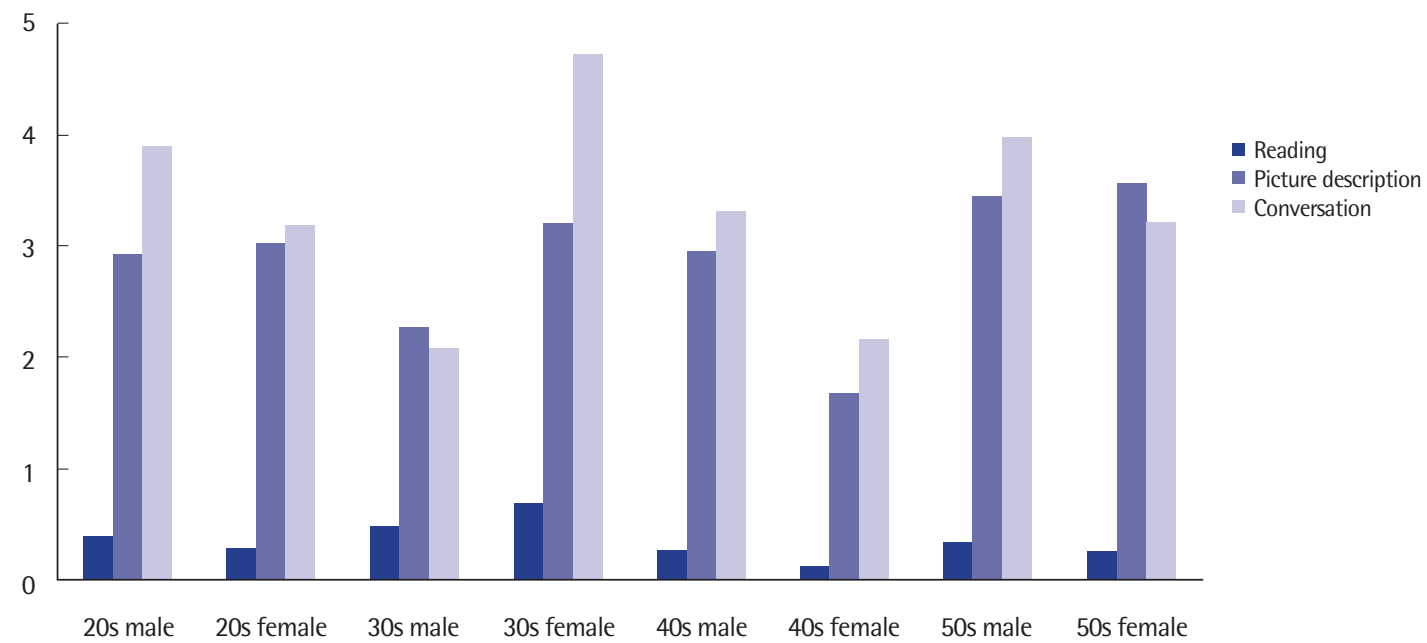

Figure 1. Normal disfluency scores of the participants in three conditions.

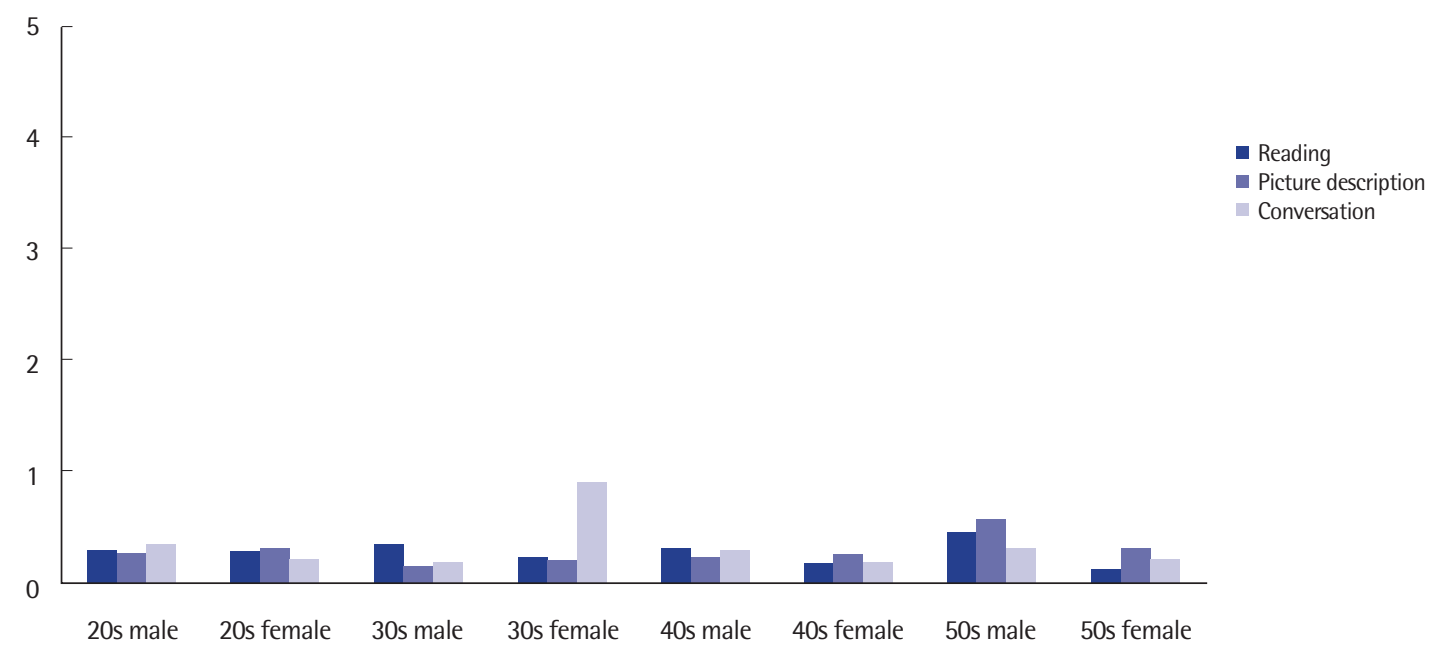

Figure 2. Abnormal disfluency scores of the participants in three conditions. 
러한 차이는 통계적으로 유의하였다 $\left(F_{(1,73)}=7.043, p=.010\right)$. 반면 나이에 따른 차이 $\left(F_{(3,73)}=.603, p=.615\right)$ 와 나이와 성별의 상호작용 $\left(F_{(3,73)}=.899, p=.446\right)$ 은 통계적으로 유의하지 않았다. 읽기의 비정 상적 비유창성의 경우, 성에 따른 차이 $\left(F_{(1,73)}=1.295, p=.259\right)$, 나이 에 따른차이 $\left(F_{(3,73)}=.021, p=.996\right)$, 성과나이의 상호작용 $\left(F_{(3,73)}=.951\right.$, $p=.421)$ 모두 통계적으로 유의하지 않았다.

대화에서 정상적 비유창성 점수는 성별 $\left(F_{(1,73)}=2.010, p=.160\right)$ 과 나이 $\left(F_{(3,73)}=2.467, p=.069\right)$ 에 따른 차이, 성별과 나이의 상호작 용 $\left(F_{(3,73)}=.301, p=.824\right)$ 이 모두 통계적으로 유의하지 않았다. 대화 의 비정상적 비유창성 점수 역시 성별 $\left(F_{(1,73)}=3.518, p=.065\right)$ 과 나이 $\left(F_{(3,73)}=1.836, p=.148\right)$ 에 따른 차이, 성별과 나이의 상호작용 $\left(F_{(3,73)}\right.$ $=.833, p=.480)$ 이 모두 통계적으로 유의하지 않았다.

그림 설명하기에서도 역시 정상적 비유창성 점수는 모두 성별 $\left(F_{(1,73)}=.106, p=.745\right)$ 과 나이 $\left(F_{(3,73)}=1.818, p=.151\right)$ 에 따른 차이가 통계적으로 유의하지 않았다. 또한 성별과 나이의 상호작용 역시 통계적으로 유의하지 않았다 $\left(F_{(3,73)}=.118, p=.949\right)$. 비정상적 비유 창성 점수 역시 성별에 따른 차이 $\left(F_{(1,73)}=.074, p=.786\right)$, 나이에 따른 차이 $\left(F_{(3,73)}=1.074, p=.366\right)$, 성별과 나이의 상호작용 $\left(F_{(3,73)}=.712\right.$,

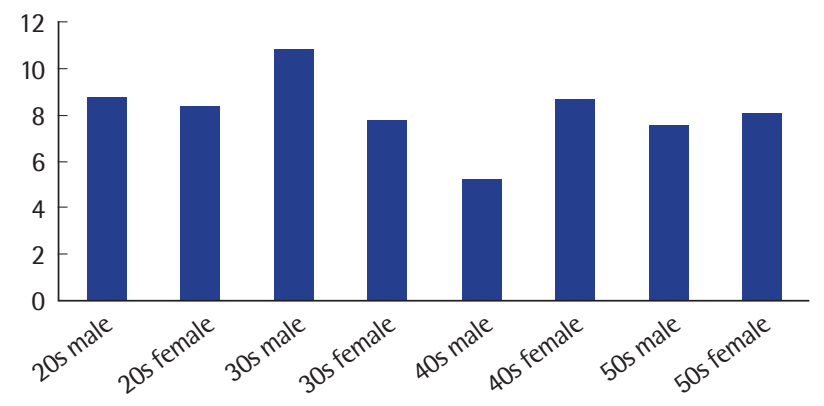

Figure 3. Communication attitude test scores of the participants. $p=.548)$ 모두 통계적으로 유의하지 않았다.

정상적 비유창성의 총점, 비정상적 비유창성의 총점, 전체 비유 창성 점수 역시 모두 성별과 나이에 따른 차이, 성별과 나이의 상호 작용 모두 통계적으로 유의하지 않았다( $p>.05)$.

\section{상황에 따른 비유창성 점수}

상황에 따른 비유창성 점수를 가장 높은 상황부터 낮은 상황으 로 배열하면, 우선 가장 높은 점수를 보인 상황은 대화의 정상적 비 유창성(평균 $3.30, \mathrm{SD}=2.14$ ), 그림 설명하기 정상적 비유창성(평균 $2.94, \mathrm{SD}=2.05)$, 읽기 정상적 비유창성(평균 $.32, \mathrm{SD}=.38$ ), 그림 설 명하기 비정상적 비유창성(평균 $.30, \mathrm{SD}=.44)$, 대화 비정상적 비유 창성(평균 $.28, \mathrm{SD}=.52$ ), 읽기 비정상적 비유창성(평균 $.28, \mathrm{SD}=.40$ ) 이었다. 이러한 상황에 따른 정상적, 비정상적 비유창성 점수의 차 이가 통계적으로 유의한지 살펴보기 위하여 반복분산측정을 실시 하였다. 실시결과, 구형성 가정을 만족시키지 못하여 $\left(\chi^{2}(14)=412.935\right.$, $p<.001)$ 그린하우스-가이저 수정치를 사용하였다. 분석결과, 상황 에 따른 차이는 통계적으로 유의하였다 $\left(F_{(1.933,159.461)}=134.648, p<\right.$ .001). 사후분석 결과, 대화의 정상적 비유창성 점수는 그림 설명하

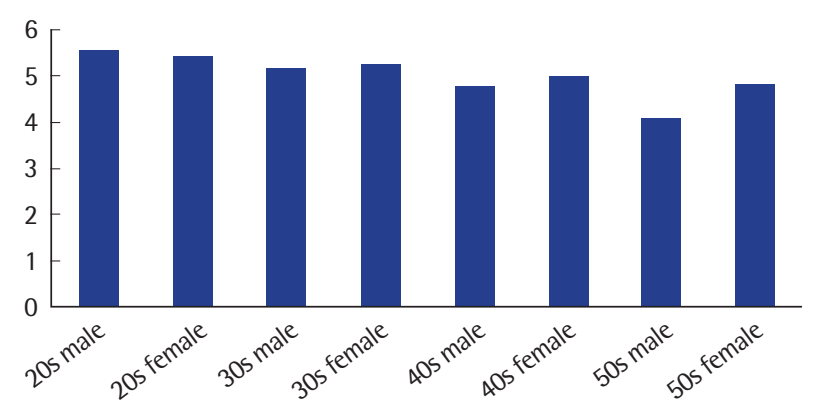

Figure 4. Overall speech rate (syllables per second) of the participants.

Table 2. Communication attitude test scores of the participants

\begin{tabular}{|c|c|c|c|c|c|c|c|c|c|c|}
\hline & \multicolumn{2}{|c|}{$20 \mathrm{~s}$} & \multicolumn{2}{|c|}{$30 \mathrm{~s}$} & \multicolumn{2}{|c|}{$40 \mathrm{~s}$} & \multicolumn{2}{|c|}{$50 \mathrm{~s}$} & \multicolumn{2}{|c|}{ Total } \\
\hline & Male & Female & Male & Female & Male & Female & Male & Female & Male & Female \\
\hline Communication attitude test & $8.77(4.49)$ & $8.40(6.43)$ & $10.86(6.15)$ & $7.80(.84)$ & $5.25(5.23)$ & $8.70(4.50)$ & $7.58(4.36)$ & $8.09(6.55)$ & $8.65(4.51)$ & $7.82(5.89)$ \\
\hline
\end{tabular}

Values are presented as mean (SD).

Table 3. Overall speech rate (syllables per second) of the participants

\begin{tabular}{|c|c|c|c|c|c|c|c|c|c|c|}
\hline & \multicolumn{2}{|c|}{$20 \mathrm{~s}$} & \multicolumn{2}{|c|}{$30 \mathrm{~s}$} & \multicolumn{2}{|c|}{$40 \mathrm{~s}$} & \multicolumn{2}{|c|}{$50 \mathrm{~s}$} & \multicolumn{2}{|c|}{ Total } \\
\hline & Male & Female & Male & Female & Male & Female & Male & Female & Male & Female \\
\hline Overall speech rate & $5.56(.49)$ & $5.42(.46)$ & $5.18(.74)$ & $5.26(.48)$ & $4.78(.60)$ & $5.00(.57)$ & $4.10(.49)$ & $4.81(.49)$ & $5.04(.75)$ & $5.17(.54)$ \\
\hline
\end{tabular}

Values are presented as mean (SD). 
기의 정상적 비유창성을 제외한 다른 모든 상황과 유의한 차이를 보였으며 $(p<.05)$, 그림 설명하기의 정상적 비유창성 점수 역시 대 화의 정상적 비유창성 점수를 제외한 모든 상황과 유의한 차이를 보였다 $(p<.05)$.

\section{성별과 나이에 따른 의사소통태도검사 점수}

본 연구 참여자의 성별과 나이에 따른 의사소통태도검사 점수는 Table 2, Figure 3과 같다. 이러한 의사소통태도검사 점수는 성별 $\left(F_{(1,73)}=.817, p=.369\right)$ 과 나이 $\left.F_{(3,73)}=.947, p=.422\right)$ 에 따른 차이가 통계적으로 유의하지 않았다. 또한 성별과 나이의 상호작용 역시 통계적으로 유의하지 않았다 $\left(F_{(3,73)}=.325, p=.807\right)$.

\section{성별과 나이에 따른 말속도 차이}

성별과 나이에 따른 읽기자료의 전체말속도는 Table 3, Figure 4 와 같다. 이러한 읽기의 전체말속도는 성에 따른 차이가 통계적으 로 유의하지 않았다 $\left(F_{(1,73)}=2.968, p=.089\right)$. 반면 나이에 따른 차이 는 통계적으로 유의하였다 $\left(F_{(1,73)}=12.044, p<.001\right)$. 사후분석 결 과, 20 대는 30 대와 유의한 차이를 보이지 않았으나 40 대, 50 대와는 유의한 차이를 보였다 $(p<.05) .30$ 대는 20 대, 40 대와 유의한 차이가 없었으나 50 대와는 유의한 차이를 보였다 $(p<.05) .40$ 대는 전술한 바와 같이 20 대와 유의한 차이를 보였으나 다른 연령대와는 유의 한 차이를 보이지 않았다. 50대는 40 대와 유의한 차이를 보이지 않 았으나 20대, 30 대와는 유의한 차이를 보였다 $(p<.05)$. 성별과 나이 의 상호작용은 통계적으로 유의하지 않았다 $\left(F_{(3,73)}=1.819, p=.151\right)$.

\section{논의 및 결론}

본 연구는 일반성인을 대상으로 연령과 성에 따라서 비유창성 빈도와 전체말속도가 차이가 나타나는지 살펴보았다. 더불어 상황 에 따라 비유창성 빈도가 차이가 나타나는지도 살펴보았다. 비유 창성 빈도의 경우 P-FA-II의 비유창성 점수로 계산하였는데, 분석 결과, 성에 따른 비유창성 점수는 유의한 차이를 보였으나 연령에 따른 점수차이는 유의하지 않았다. 또한 이러한 비유창성 점수는 상황에 따라 유의한 차이가 나타났다. 전체말속도는 성에 따른 차 이는 유의하지 않았으나 연령에 따른 차이는 유의하였다. 의사소통 태도는 성과 연령에 따른 차이가 유의하지 않았다. 이를 좀 더 자세 히 논의하면 다음과 같다.

\section{비유창성 빈도의 변이성}

본 연구 결과, 성과 나이에 따른 비유창성의 변이성은 본 연구에
참여한 일반성인의 경우, 제한적인 것으로 나타났다. 세 가지 과제 의 정상적 비유창성 점수와 비정상적 비유창성 점수, 그리고 총점 등을 대상으로 성별과 나이에 따라 유의한 차이를 살펴본 결과, 읽 기의 정상적 비유창성에서만 성에 따라서 유의한 차이가 나타났으 며 그 외의 상황에서는 유의한 차이가 관찰되지 않았다. 좀 더 자세 히 결과를 살펴보면 남성이 여성보다 읽기에서 정상적 비유창성을 유의하게 더 많이 보였다. 이러한 성에 따른 패턴은 전체적으로 관 찰은 되었으나 이외의 상황에서는 통계적으로 유의한 차이는 아니 었다. 전체 정상적 비유창성 점수와 전체 비정상적 비유창성 점수, 그리고 전체 비유창성 점수에서 모두 남성이 여성보다 높은 패턴을 보였다. 이와 같은 본 연구결과는 남성이 여성보다 비유창성을 더 많이 보인다는 이전 연구와 유사한 결과이다(Bortfeld et al., 2001;

Kools \& Berryman, 1971; Tumanova et al., 2014).

본 연구의 참여자는 비유창성의 문제가 없는 일반 성인이었으나 비유창성의 빈도는 상황별로 유의한 차이를 보였는데, 이는 일반적 인 비유창성 발생의 특성인 것으로 생각된다. 말더듬의 가장 큰 특 징 중의 하나는 비유창성이 상황에 따라 다르게 나타난다는 것이 며, 일반적으로 부담이 낮은 상황보다는 높은 상황에서, 읽기보다 는 자발화 과제에서 비유창성을 더 많이 보이는 것으로 알려져 있 다(Bloodstein \& Bernstein Ratner, 2008). 비록 회피와 대치 등을 사용하는 말더듬성인은 개인적인 특성에 따라 자발화보다는 읽기 에서 비유창성을 더 많이 보일 수도 있다고 제시되고 있으나 일반 적으로 자기주장성 발언 등과 같은 자발화에서 비유창성을 많이 보인다고 할 수 있다(Guitar, 2014). 이와 관련하여 비유창성은 언어 를 구성해야 하는 어려움과 관련이 있을 수 있으므로 읽기보다는 자발화과제인 대화와 그림 설명하기에서 비유창성이 더 높았던 것 으로 볼 수 있다. 이처럼 상황에 따른 변이성과 언어과제의 내재적 인 특성 등으로 인하여 일반성인 역시 비유창성의 변이성을 보였을 것이다.

또한 연령에 따른 비유창성 점수는 유의한 차이를 보이지 않았 는데, 이는 본 연구 대상자 연령의 특성인 것으로 보인다. 연령에 따 라 비유창성의 유의한 차이를 보고한 연구는 일반적으로 노년층을 대상으로 한 연구나 상대적으로 젊은 성인과 노년층과의 비교연구 였다(Duchin \& Mysak, 1987; Leeper \& Culatta, 1995; Shin, 2016). 하지만 본 연구의 참여자는 60 세 미만의 성인으로 노년층이 제외 된 청장년층을 주요 대상으로 하였다. 즉 이와 같은 결과는 노화로 인하여 비유창성의 변화가 나타날 수는 있으나 청장년층의 경우 나이에 따른 비유창성의 빈도 변화가 크지 않음을 나타낸다. 


\section{일반성인의 비유창성 특성과 의사소통태도 점수}

본 연구 결과, 일반성인 역시 일정 수준의 비유창성을 보였으며, 이와같은 결과는 말더듬성인의 평가에서는 비유창성의 종류와같 은 질적 평가가 중요함을 다시 한 번 강조한다. 학령전기 말더듬아 동 평가의 주요 목표로는 아동의 말더듬여부와 자연치유가능성 등을 측정하는 것이며, 일반적으로 말더듬성인의 평가에서는 이와 같은 목표는 임상적으로 크게 강조되지 않는다(Manning, 2010). 이는 말더듬성인은 자신이 말더듬는 사람이라는 것을 이미 알고 있으며, 자연치유가능성 역시 매우 낮기 때문이다. 말더듬성인의 평가에서 말더듬여부 판정이 평가의 주요목표는 아니겠으나 일반 성인과의 비교를 통하여 말더듬성인의 말 특성과 말더듬중증도를 보다 효율적으로 기술할 수 있을 것이다. 이와 관련하여 겉으로 드 러나는 외적 특성으로 말더듬의 중증도를 평가하는 경우가 많다. 외국 평가도구인 말더듬 정도 측정표(Stuttering Severity Instrument for Children and Adults 4, SSI-4; Riley, 2009)에서는 비정상 적 비유창성의 빈도, 비유창성의 지속시간, 부수행동 등의 총점으 로 중증도를 측정하고 있으며 비유창성 빈도 측정에 정상적 비유 창성은 포함하지 않고 있다. 본 연구에서 사용한 P-FA-II에서는 정 상적 비유창성과 비정상적 비유창성의 빈도 모두 말더듬의 중증도 에 포함하고 있다(Sim et al., 2010). 즉, 정상적 비유창성과 비정상적 비유창성의 빈도를 합산하는데 특히 정상적 비유창성이 질적 양상 을 보이는 경우, 비정상적 비유창성으로 판단하며, 비정상적 비유 창성에 가산점을 부여하고 있다. 이는 단순히 유형 자체만으로 평 가할 때 말더듬의 문제를 과소평가하는 것을 방지하기 위함이라고 매뉴얼에 제시되어 있다. 이와 관련하여 본 연구의 일반성인 20 대 남성 참여자의 세 필수과제의 정상적 비유창성 총점은 평균 7.21점, 비정상적 비유창성의 총점은 평균 0.9 점으로 세 필수과제의 비유 창성 총점은 8.1점이다. 이와 같은 점수는 P-FA-II 기준에 따르면 말 더듬정도는 약함, 백분위점수는 21-30\%ile에 해당하는 수준이다. 즉, 일반성인이라 할지라도 P-FA-II에서 제시한 기준에 따르면 약 함 수준으로 말더듬 문제를 보이고 있는 것으로 진단될 수 있다는 점에서 평가결과의 해석에서 주의가 필요해 보인다. 이와 관련하여 많은 연구자들이 단순히 비유창성의 전체 빈도보다는 유형 등과 같은 질적 특성이 평가와 중증도 산정에 중요하다는 점을 인정하고 있다. 예를 들어 Yairi와 Ambrose (2005)는 가중치를 둔 SLD 점수 를 제시하고 있는데, 이들은 같은 비정상적 비유창성일지라도 막힘 과 연장과 같은 비운율적 발성과 반복의 횟수에 가중치를 두어 비 유창성 빈도 점수를 산출한다. 이러한 가중치 부여는 본 연구에서 사용한 P-FA-II에서도 마찬가지로 비정상적 비유창성에 1.5 배의 가중치가 부여된다. 이에 이와 같은 가중치를 고려한다면 본 연구
에 참여한 일반성인의 경우 정상적 비유창성과 비정상적 비유창성 의 빈도비율은 약 9:1인 것으로 볼 수 있다. 이러한 점들을 고려해볼 때 말더듬성인의 평가에서는 단순히 평가도구의 총점분석을 통한 중증도 측정뿐 아니라 비유창성의 질적 분석을 통한 전체적인 비 유창성의 특성을 기술하는 것이 더 중요할 수 있으며, 이를 통하여 말더듬성인과 일반성인의 감별진단을 하는 것이 필요하다.

더불어 이와 같은 본 연구의 결과는 치료목표 선정과도 관련이 있을 수 있다. 말더듬치료의 목표는 여러 가지가 있을 수 있으나 가 장 기본적인 목표는 유창성의 증진일 것이다. 하지만 이번 일반성인 의 결과를 보면 완벽한 수준으로의 유창성 획득은 현실적으로 가 능한 목표가 아니라는 점을 이해하는 것이 필요하다. 이와 관련하 여 Manning (2010)은 유창성 수준의 향상뿐 아니라 비정상적 비유 창성에서 정상적 비유창성으로의 유형 변화 역시 주요한 치료 변화 의 지표일 수 있음을 지적하였다. 더불어 일반인 역시 완벽한 유창 성을 보이는 것이 아니라 말더듬평가에서 "약함" 수준의 중증도 로 진단받을 수도 있다는 점을 말더듬치료 대상자가 인지하는 것 이 필요하며 치료사 역시 성인의 정상 유창성 수준에 대한 기준을 이해하는데 도움이 될 것이다.

또한 본 연구의 일반성인 참여자는 의사소통태도에서 성별과 나 이에 따른 차이가 통계적으로 유의하게 나타나지 않았다. 이와 관 련하여 P-FA-II에서는 말더듬청소년과 일반청소년의 의사소통태 도 점수를 개별적으로 보고하고 있지 않으나 본 연구의 일반성인 참여자의 의사소통태도평가 점수는 중학생이상의 말더듬성인과 비교하였을 때 $10 \%$ ile에 해당하는 점수이다. 이와 같은 결과는 비 유창성과 비교, 의사소통태도가 말더듬는 사람과 일반인을 비교 할 수 있는 매우 중요한 요인이라는 점을 시사한다. 이러한 결과에 비추어 볼 때 성에 따른 의사소통태도와 말더듬성인에 대한 태도 등의 차이에 대한 연구는 지속적으로 진행될 필요가 있다.

\section{일반성인의 전체 말속도}

일반적으로 말속도는 과제 등에 따라서 매우 가변적인 특성을 보 이는데, 본 연구 참여자들은 읽기 상황에서 초당 4.1-5.56음절의 상 대적으로 빠른 전체말속도를 보였다. 이는 본 연구에서는 자발화가 아닌 읽기를 대상으로 전체말속도를 측정한 것과 관련이 있어 보인 다. 전체말속도의 경우 일정수준 이하의 휴지기 등은 포함하는데, 읽기 과제의 경우, 언어적인 부담감이 낮기 때문에 상대적으로 휴 지기가 짧아서 전체말속도가 상대적으로 빠르게 나온 것으로 볼 수 있다. 일반성인의 전체말속도를 구한 다른 연구에서도 읽기에서 는 $348 \mathrm{SPM}$ (초당 5.8음절), 대화에서는 $265 \mathrm{SPM}$ (초당 4.41음절) 으로 읽기에서 더 빠른 말속도를 보고하였다(Shin \& Han, 2003). 
전체말속도의 경우 성별에 따른 차이는 유의하지 않았으나 연령 에 따른 차이는 통계적으로 유의하였다. 대략적으로 살펴보면 상대 적으로 어린 성인 연령대인 20대와 30 대는 상대적으로 높은 연령대 인 40대, 50대와 비교, 유의하게 빠른 전체말속도를 보였다. 연령대 가 높아질수록 신경학적인 원인 등으로 느린 조음속도, 전체말속 도, 교대운동속도 등을 보일 수 있는데(Jeon et al., 2011; Kahane, 1981; Lee, 2011), 본 연구 결과, 말속도의 변화가 상대적으로 이른 나이대인 40 대부터 관찰되었다. 이와 같은 결과는 45 세-54세 집단 이 이보다 어린 성인 연령대 집단보다 유의하게 느린 전체말속도를 보였다는 Kim (2008)과 유사한 결과로, 이에 중장년층의 말더듬성 인의 평가와 치료에서는 이와 같은 점을 고려하여야할 것이다.

또한 성별에 따른 전체말속도에서 유의한 차이가 나타나지 않았 으나 기타 다른 상황에서 성별에 따른 차이가 나타나는지 후속 연 구에서는 살펴볼 필요가 있을 것이다. 전술하였듯이 전체말속도는 과제에 따른 차이가 나타날 수 있으므로 발화 과제의 난이도와 언 어부담 등이 다양한 상황에서 성별에 따른 차이가 어떻게 나타나 는지 살펴볼 필요가 있을 것이다. 특히 본 연구 결과, 남성 참여자가 읽기에서 비록 여성 참여자보다 높은 정상적 비유창성 점수를 보였 으나 전체말속도 평가에서는 성별에 따른 전체말속도의 차이가 통 계적으로 유의하지 않았다. 즉 이와 같은 결과는 오히려 읽기에서 의 남성의 조음속도가 여성에 비해 빠를 수도 있다는 점을 시사한 다. 이에 후속 연구에서는 연령, 과제 등에 따라 남성과 여성이 어떻 게 말속도를 보이는지 살펴볼 필요가 있을 것이다.

\section{본 연구의 제한점과 제언}

우선 본 연구는 참여자의 연령 등 특성과 관련된 제한점이 있다. 본 연구에서는 만 20 세 이상 60 세 미만의 성인 남녀가 참여하였으 나 연령대별로 성별의 비율이 동일하지 않았다. 이에 본 연구결과 의 해석에는 주의가 필요하다. 그럼에도 불구하고 본 연구에서는 연령에 따른 비유창성의 차이가 통계적으로 유의하지 않았다. 즉 이와 같은 결과는 청년과 중장년층을 대상으로 한 말더듬 빈도의 평가에서는 연령에 따른 차이를 크게 고려할 필요가 없다는 점을 나타낸다. 하지만 본 연구에는 60 대 이상의 노년층이 참여하지 않 았기에 말더듬성인의 전 생애적인 특성을 살펴보기 위한 노년층을 포함하는 연구가 필요하다(Bloodstein \& Bernstein Ratner, 2008). 비록 60세 이상의 말더듬노년층이 임상에서 주된 대상자가 아닐지 라도 말더듬의 전 생애적 조망과 기타 다른 신경학적 장애 등과의 비교라는 관점에서 이들을 포함한 연구가 필요할 것이다. 또한 현 P-FA-II에서는 중학생 이상의 성인을 대상으로 하고 있기에 중.고 등학생과 성인의 비교 역시 필요할 것이다.
또한 본 연구가 비유창성의 가변성 등과 관련하여 다양한 상황 에서의 말 자료를 분석하였으나 이후 연구에서는 보다 다양한 상 황에서의 말 자료를 분석할 필요가 있다. 본 연구에서는 이와 같은 비유창성의 다양성을 고려하여 임상에서 가장 많이 사용되는 PFA-II의 세 가지 필수과제를 사용하여 발화의 비유창성을 분석하 였다. 하지만 비유창성은 언어 및 상황 부담감 등에 따라서 다르게 나타날 수 있으므로 전화 상황, 모르는 사람과의 대화 등의 발화자 료를 수집하고 분석하기도 한다(Guitar, 2014). 본 연구결과에서 나 타났듯이 일반성인도 상황에 따라 비유창성의 가변성을 보이기에 보다 더 다양한 상황에서의 비유창성을 측정하여 이를 말더듬성 인과 비교할 필요가 있을 것이다. 특히 이와 관련하여 성과 상황에 따른 상호작용 등을 고려할 필요가 있을 것이다. 일반적으로 말더 듬의 발생율은 성별에 따라 다르며 남성이 여성보다 더 높은 편이 며(Guitar, 2014; Yairi \& Ambrose, 2013), 본 연구도 이와 유사한 결 과를 보고하였다. 특히 본 연구에서는 이와 같은 성에 따른 비유창 성의 발생 차이가 읽기에서 나타났으나 이전 연구에서는 대화 상황 에서의 성별에 따른 차이를 보고하였다(Bortfeld et al., 2001; Kools \& Berryman, 1971; Tumanova et al., 2014). 이와 관련하여 본 연구 에서는 성과 상황에 따른 상호작용을 살펴보지 않았기에 후속 연 구에서는 상황별로 남녀의 비유창성이 어떻게 다르게 나타날 수 있는지에 대한 연구가 필요할 것이다. 이를 통하여 말더듬성인의 평 가, 특히 말더듬여성의 평가에서 어떠한 상황에 더 주의를 기울여 야할 지살펴볼수 있을 것이다.

더불어 본 연구에서는 비유창성의 세부 유형에 따른 성별, 연령별 차이를 살펴보지 않았으나 후속 연구에서는 이와 관련된 연구가 필 요할 것이다. 전술하였듯이 본 연구결과, 제한적이기는 하지만 남성 이 여성보다 더 많은 비유창성을 보였으나 본 연구의 일반인 참가자 는 전체적으로 매우 적은 수의, 약 100 음절당 3 회 정도의 정상적 비 유창성을 보였기에 이렇듯 상대적으로 적게 나타나는 비유창성을 그 유형별로 나누어 분석을 하지 않았다. 하지만 이후 연구에서는 과업의 종류와 난이도 등을 조절한 발화샘플에서 나타나는 비유창 성 발생의 성별 차이를 살펴보는 것이 필요할 것이다. 이와 관련하여 이전 연구에서는 남성이 대화 상황에서 간투사 등을 더 많이 사용 하며, 이는 대화의 주도권을 잡기 위한 것으로 해석되고 있다(Leeper \& Culatta, 1995). 이에 남녀의 특성의 차이가 비유창성의 유형에 어떠한 영향을 줄수 있는지 보다 심화된 연구가 필요할 것이다.

이와 같은 가변성과 관련된 제한은 말속도에도 역시 적용된다. 본 연구에서는 임상에서 쉽게 측정하고 비교할 수 있도록 읽기를 대상으로 하였고 비교적 손쉽게 측정할 수 있는 Praat을 사용하여 전체말속도를 측정하였으나 이후 연구에서는 그림 설명하기나 대 
화와 같은 자발화 과제에서의 일반인과 말더듬성인의 말속도를 비 교할 필요가 있을 것이다. 또한 말산출 체계의 안정성 등을 비교하 기 위해서는 전체말속도 이외에도 조음속도 등을 비교할 필요가 있을 것이다.

\section{결론}

일반성인을 대상으로 비교적 높은 신뢰도를 보인 방법을 통해 연 령과 성별에 따라 비유창성과 전체말속도를 살펴본 결과, 일반인 역시 상황에 따른 비유창성의 가변성을 보였으며, 말속도의 경우 성별보다는 연령에 따른 차이가 나타났다. 이에 말더듬성인, 특히 약함 정도의 중증도를 보이는 말더듬성인의 평가에서는 비유창성 의 양적 평가보다는 질적 평가가 중요할 것이다. 더불어 말더듬이 개별적, 다면적 장애이기에 평가와 치료의 목표 역시 개별적으로 다양하게 진행되어야 할 것이다.

\section{REFERENCES}

Ahn, J. B., Shin, M. S., \& Kwon, D. H. (2002). The study of speech rate in normal speaking adults and children. Korean Journal of Speech Sciences, 9, 93103.

Bloodstein, O., \& Bernstein Ratner, N. (2008). A handbook on stuttering (6th ed.). Clifton Park, NY: Thomson Delmar Learning.

Boersma, P., \& Weenink, D. (2013). Praat: doing phonetics by computer (version 6.0.28) [Software]. http://www.praat.org/.

Bortfeld, H., Leon, S. D., Bloom, J. E., Schober, M. F., \& Brennan, S. E. (2001). Disfluency rates in conversation: effects of age, relationship, topic, role, and gender. Language and Speech, 44, 123-147.

Chon, H. (2015). Measurement of overall speech rate and articulation rate. In D. Ko (Ed.), Experimental phonetics for speech-language pathologists (pp. 271-290). Seoul: Hakjisa.

Chon, H., Ko, D., \& Shin, M. (2004). Disfluency characteristics and speech rate of stuttering and nonstuttering. Korean Journal of Communication \& Disorders, 9, 102-115.

Duchin, S. W., \& Mysak, E. D. (1987). Disfluency and rate characteristics of young adult, middle-aged, and older males. Journal of Communication Disorders, 20, 245-257.

Guitar, B. (2014). Stuttering: an integrated approach to its nature and treatment (4th ed.). Philadelphia, PA: Lippincott Williams \& Wilkins.

Guttormsen, L. S., Kefalianos, E., \& Naess, K. B. (2015). Communication attitudes in children who stutter: a meta-analytic review. Journal of Fluency
Disorders, 46, 1-14.

Jeon, H., Kim, H., Shin, M., \& Chang, H. (2011). Speech fluency characteristics of adults in their manhood and senescence. The Journal of the Korea Contents Association, 11, 318-326.

Kahane, J. C. (1981). Anatomic and physiologic changes in the aging peripheral speech mechanism. In D. S. Beasley \& G. A. Davis (Eds.), Aging communication processes and disorders (pp. 21-45). New York, NY: Gune and Stratton.

Kim, B. (2008). Maximum phonation time and articulation diadochokinetic rate, speech rate of standardized passage in the healthy Korean youths and middle-agers (Master's thesis). Yonsei University, Seoul, Korea.

Kim, M., Lee, K., Choi, S., \& Choi, C. (2016). Disfluency and communication attitudes of preschool children from multicultural backgrounds. Journal of Speech-Language \& Hearing Disorders, 25, 201-212.

Kools, J. A., \& Berryman, J. D. (1971). Differences in disfluency behavior between male and female nonstuttering children. Journal of Speech, Language, and Hearing Research, 14, 125-130.

Lee, G., \& Kwon, D. (2004). The study of disfluency types and speech rate in school-aged children. Journal of Speech-Language \& Hearing Disorders, 13, 79-88.

Lee, H. K. (2010). The comparison of reading rate and pausal behavior between normal adults and stuttering adults (Master's thesis). Ewha Womans University, Seoul, Korea.

Lee, J. S., Sim, H. S., \& Lee, S. B. (2013). Communication attitude in 3-to 5-yearold children who do and do not stutter. Special Education Research, 12, 5-22.

Lee, S. (2011). Overall speaking rate and articulation rate of normal elderly people (Master's thesis). Yonsei University, Seoul, Korea.

Lee, S., Sim, H., \& Shin, M. (2007). Disfluency characteristics in preschool bilingual children. Korean Journal of Communication \& Disorders, 12, 296-316. Leeper, L., \& Culatta, R. (1995). Speech fluency: effect of age, gender, and context. Folia Phoniatrica et Logopaedica, 47, 1-14.

Lutz, K. C., \& Mallard, A. R. (1986). Disfluencies and rate of speech in young adult nonstutterer. Journal of Fluency Disorders, 11, 307-316.

Manning, W. H. (2010). Clinical decision making in fluency disorders (3rd ed.). Clifton Park, NY: Delmar Cengage Learning.

Riley, G. (2009). Stuttering Severity Instrument for Children and Adults (4th ed.). Austin, TX: Pro-Ed.

Robb, M. P., Maclagan, M. A., \& Chen, Y. (2004). Speaking rates of American and New Zealand varieties of English. Clinical Linguistics \& Phonetics, 18, $1-15$. 
Shim, H. (2005). A study of disfluency characteristics and speech rates in normal Korean adults (Doctoral dissertation). Hallym University, Chuncheon, Korea.

Shin, H. (2016). Characteristics of disfluency according to aging and types of speech production task. (Master's thesis). Yonsei University, Seoul, Korea.

Shin, M., \& Han, S. (2003). A study of speech rate and fluency in normal speakers. Korean Journal of Speech Sciences, 10, 159-168.

Silverman, E. M., \& Zimmer, C. H. (1979). Women who stutter: personality and speech characteristics. Journal of Speech and Hearing Research, 22, 553564.

Sim, H. S., Shin, M. J., \& Lee, E. J. (2010). Paradise-Fluency Assessment-II. Seoul: Paradise Welfare Foundation.

St. Louis, K. O. (2012). Male versus female attitudes toward stuttering. Jour- nal of Communication Disorders, 45, 246-253.

Tumanova, V., Conture, E. G., Lambert, E. W., \& Walden, T. A. (2014). Speech disfluencies of preschool-age children who do and do not stutter. Journal of Communication Disorders, 49, 25-41.

Walker, V. G. (1988). Durational characteristics of young adults during speaking and reading tasks. Folia Phoniatrica, 40, 12-20.

Yairi, E., \& Ambrose, A. (2013). Epidemiology of stuttering: 21st century advances. Journal of Fluency Disorders, 38, 66-87.

Yairi, E., \& Ambrose, N. G. (2005). Early childhood stuttering for clinicians by clinicians. Austin, TX: Pro Ed.

Yairi, E., \& Clifton, N. F. (1972). Disfluent speech behavior of preschool children, high school seniors, and geriatric persons. Journal of Speech, Language, and Hearing Research, 15, 714-719. 


\section{국문초록}

\section{일반성인의 연령과 성에 따른 비유창성 빈도, 말속도와 의사소통태도}

신문자 $\cdot$ 이경재 ${ }^{2}$

'조선대학교 언어치료학과, ${ }^{2}$ 대구가톨릭대학교 언어청각치료학과

배경 및 목적: 비유창성은 가변성이 매우 큰 특성을 지니고 있어 적절한 말더듬 평가를 하기 위해서는 다양한 상황에서의 말 샘플을 분석하여야 하지만 말더듬성인의 평가해석에 사용될 수 있는 일반성인의 비유창성 변이성에 대한 연구는 부족한 편이다. 더불어 말속 도 역시 말더듬 치료 진전의 지표로 사용될 수 있으나 이전 연구들은 연구방법의 차이 등으로 인하여 임상 현장에서 직접적인 비교를 하기에는 어려움이 있었다. 이에 본 연구에서는 말더듬성인의 평가와 치료에서 임상현장에서 직접적으로 사용될 수 있도록 일반성인 의 비유창성과 말속도를 측정하였으며, 이러한 비유창성과 말속도가 성과 연령에 따라 차이가 있는지 살펴보고자 하였다. 더불어 말더 듬의 다면적인 평가를 하기 위하여 측정되는 의사소통태도가 일반인의 경우, 성별과 연령에 따라 차이가 나타나는지 살펴보고자 하였 다. 방법: 총 81 명의 일반성인(평균연령 36.56 세, 남 37 명, 여 44 명)이 본 연구에 참여하였다. 참여자를 대상으로 임상현장에 가장 널리 사용되는 파라다이스-유창성평가-II의 필수과제를 실시하여 각 상황별 정상적 비유창성 점수와 비정상적 비유창성 점수를 측정하였 다. 더불어 읽기자료를 대상으로 전체말속도를 측정하였으며 의사소통태도검사도 실시하였다. 이렇게 산출한 비유창성 점수, 전체말속 도, 의사소통태도 점수가 성별과 연령집단에 따라 차이가 나타나는지 이원분산분석과 반복분산분석을 통하여 살펴보았다. 결과: 일 반성인의 비유창성의 빈도에서 성에 따른 차이는 제한적이었으며 연령에 따른 차이는 유의하지 않았다. 전체말속도의 경우 성에 따른 차이는 유의하지 않았으나 연령에 따른 차이는 유의하였다. 의사소통태도는 성과 연령에 따른 차이가 유의하지 않았다. 논의 및 결론: 말더듬성인의 평가에서 비유창성의 양적 특성뿐 아니라 질적 특성을 살펴보는 것이 중요하다는 점을 본 연구결과는 시사한다. 더불어 전 생애적인 말더듬의 발달과 관련하여 보다 다양한 연령대의 집단이 연구되어야 할 것이다.

핵심어: 비유창성, 전체말속도, 의사소통태도, 말더듬평가

본 연구는 2017학년도 조선대학교 학술연구비의 지원을 받아 연구되었음.

\section{참고문헌}

김민영, 이경재, 최성희, 최철희(2016). 학령전기 다문화가정아동의 비유창성과 의사소통태도. 언어치료연구, 25, 201-212.

김부영(2008). 청·장년층의 최대발성시간, 조음교대운동속도 및 표준문구발화속도. 연세대학교 대학원 석사학위논문.

신문자, 한숙자(2003). 정상성인의 말속도 및 유창성 연구.음성과학 10,159-168.

신혜정(2016). 노화와발화산출 과제 유형에 따른 비유창성 특성. 이화여자대학교 대학원 석사학위논문.

심현섭, 신문자, 이은주(2010). 파라다이스-유창성 검사-II. 서울: 파라다이스 복지재단.

심홍임(2005). 정상 성인의 비유창성 특징과 말 속도에 관한 연구. 한림대학교 대학원 박사학위논문.

안종복, 신명선, 권도하(2002). 정상 성인 및 아동의 구어속도에 관한 연구. 음성과학, 9, 93-103.

이강현, 권도하(2004). 학령기 아동의 비유창성 유형과 구어속도에 관한 연구. 언어치료연구, 13, 79-88.

이상은(2011). 정상 노인의 전체말속도와조음속도. 연세대학교 대학원 석사학위논문.

이수복, 심현섭, 신문자(2007). 취학전 이중언어아동의 비유창성 특성. 언어청각장애연구, 12, 296-316.

이지숙, 심현섭, 이수복(2013). 3-5세 일반아동과 말더듬아동의 의사소통태도 특성. 특수교육, 12, 5-22.

이현경(2010). 말더듬 성인과 정상 성인의 읽기속도와 쉼특성 비교. 이화여자대학교 대학원 석사학위논문.

전희숙, 김효정, 신명선, 장현진(2011). 장.노년기 성인의 유창성 특성 연구. 한국콘텐츠학회논문지, 11, 318-326.

전희정(2015). 전체말속도 및 조음속도 측정. 음성언어의 측정, 분석 및 평가(고도흥 편저). 서울: 학지사.

전희정, 고도흥, 신문자(2004). 유창성장애 아동과 정상 아동의 비유창성과 말 속도에 관한 비교 연구 언어청각장애연구, 9, 102-115. 